九州大学学術情報リポジトリ

Kyushu University Institutional Repository

\title{
Optimization of Solar, Wind and Biomass-Based Hybrid Renewable Energy System in St. Martin's Is land, Bangladesh
}

Ankur Das Avi

Department of Electrical and Electronic Engineering, Chittagong University of Engineering and Technology (CUET)

Fayaz, Tiham

Department of Electrical and Electronic Engineering, Chittagong University of Engineering and Technology (CUET)

Bidyut Baran Saha

International Institute for Carbon-Neutral Energy Research (WPI-I2CNER), Kyushu University

Ghosh, Sampad

Department of Electrical and Electronic Engineering, Chittagong University of Engineering and Technology (CUET)

https://doi.org/10.5109/4738577

出版情報: Proceedings of International Exchange and Innovation Conference on Engineering \& Sciences (IEICES). 7, pp. 122-128, 2021-10-21. 九州大学大学院総合理工学府

バージョン:

権利関係: 


\title{
Optimization of Solar, Wind and Biomass-Based Hybrid Renewable Energy System in St. Martin's Island, Bangladesh
}

\author{
Ankur Das Avi ${ }^{1}$, Tiham Fayaz ${ }^{1}$, Bidyut Baran Saha ${ }^{2,3}$, Sampad Ghosh $^{1 *}$ \\ ${ }^{1}$ Department of Electrical and Electronic Engineering, Chittagong University of Engineering and Technology (CUET), \\ Chattogram, Bangladesh \\ ${ }^{2}$ International Institute for Carbon-Neutral Energy Research (WPI-I $\left.{ }^{2} \mathrm{CNER}\right)$, Kyushu University, Fukuoka, Japan \\ ${ }^{3}$ Department of Mechanical Engineering, Kyushu University, Fukuoka, Japan \\ *Corresponding author email: sampad@cuet.ac.bd
}

\begin{abstract}
Hybrid renewable energy system (HRES) is an evolving power generation strategy that requires a combination of various energy resources and is common in modern pursuits. Allowing features, such as low CO $\mathrm{O}_{2}$ emissions, less environmentally damaging possibilities than traditional power generation techniques, and mostly unlimited power resources give more flexibility. Along with connecting these HRES power plants with the national grid for the addition of more power generation, electrification of remote areas is possible with stand-alone power plants. The proposed research model is a quantitative study on the potentiality of renewable sources in St. Martin's Island, a geographically important location of Bangladesh. This work incorporates solar, wind, and biomass sources in the HRES system, which is a relatively new concept when compared with other HRES strategies with a levelized cost of \$0.18. An enhanced HRES model is proposed considering different constraints revealing a new possibility of power generation on that island.
\end{abstract}

Keywords: Biomass; HOMER Software; Hybrid Renewable Energy System (HRES); Solar; Wind.

\section{INTRODUCTION}

Energy has been an indispensable necessity for human survival in recent periods. Energy demand is growing due to demographic growth, economic and technological progression [1]. Fossil fuel serves much of the planet's energy needs [2], resulting majority of the electric power generation is based on fossil fuels (e.g., coal, diesel, and natural gas $[3,4])$. More specifically, natural gas provides about $35 \%$ of the world's primary energy supply [5]. The most concerning aspect is that the globe will offer coal for 122 years, oil for 42 years, and natural gas for 60 years, considering the recent fossil asset supply and deployment rates [6]. Overall, there would be a $36 \%$ rise in fossil fuel intake between 2011 and 2030 if the average demand level is $1.6 \%$ [7]. Interestingly, over the recent decades, the dreadful circumstances of stand-in fossil fuels have been observed worldwide. The consumption rate for fossil fuels is rising dramatically, equal to insufficient reserves. Even while non-fossil sources have deteriorated by $10.8 \%$ over the last two decades, global fossil-based electricity generation has increased by $13 \%$ [8]. In addition, the production of electricity from fossil fuels produces an immense volume of greenhouse gas, which is the primary source of global warming [9]. Across the planet, the effects of changing climate on human and biological processes have already been observed [10,11]. This temperature rise is almost definitely the consequence of the anthropogenic emission of greenhouse gases, more than half of which are emitted by fossil fuel combustion [10]. The use of fossil fuels has been brought into question by these ever-growing issues [9].

Bangladesh is a developing country in the Southeast Asian subcontinent with a rapidly increasing population and economy, having almost $75-80 \%$ of the total population dwell in the rural areas $[12,13]$. The country's GDP growth (annual $\sim 6 \%$ ) and the energy consumption rate are rising significantly [12]. Energy plays an important role in the country's financial as well as social development [8]. Recently, the Government of Bangladesh has introduced a scheme named 'Hundred Percent Electrification' to improve electricity supply $[14,15]$. Through this scheme, Bangladesh has attained
$97 \%$ access to electricity in the 2019-2020 fiscal year and produced 23,548 MW of electricity with captive and renewable resources [15]. However, the worrisome part is that only $\sim 715 \mathrm{MW}$ of energy is generated from renewable resources, covering only $\sim 3 \%$ of electricity production [16]. So, the Govt. has set an aim of upgrading the consumption of renewable resources up to $10 \%$ in the future [15]. Currently, solar radiation, wind speed, and biomass are the major renewable resources commonly used in Bangladesh [17]. In a recent report by the Sustainable Renewable Energy Development Authority (SREDA), Bangladesh has disclosed that the current Government has a vision of generating $3493 \mathrm{MW}$ of electricity from photovoltaics (PV) by 2041, 1360 MW from wind power by 2030, and 31.06 MW from biogas/biomass by 2021 [18-21]. Therefore, it is evident that modern power demand heeds us to consider the hybrid renewable energy system (HRES).

Due to the potentialities according to the national and global context, it is crucial to focus on large HRES ideas. That's why this study is focusing on optimization and modeling of an integrated HRES model in one of the country's priority islands with support of RE sources such as solar, wind, and biomass. Besides, this study has an attempt of least possible $\mathrm{CO}_{2}$ emission along with efficient and clean power generation.

\subsection{Proposed location}

St. Martin, the only coral island of Bangladesh, is located in between $20^{\circ} 34^{\prime}$ and $20^{\circ} 39^{\prime} \mathrm{N}$ and $92^{\circ} 18^{\prime}$ and $92^{\circ} 21^{\prime} \mathrm{E}$, locally known as "Narikel Jinjira" (Coconut Island) [22]. It is separated from the mainland by the Naaf Channel and plays a part in establishing Bangladesh's southernmost region, which is $\sim 7.5 \mathrm{~km}$ long and $\sim 1.5 \mathrm{~km}$ wide $[23,24]$. The average monthly air temperature is between 27 to $32{ }^{\circ} \mathrm{C}$, with a minimum of 16 to $26^{\circ} \mathrm{C}$. The relative humidity is least in February $(\sim 65 \%)$ and most in July $(90 \%)$. With a little (0 to $88 \mathrm{~mm})$ and high (239 to $309 \mathrm{~mm}$ ) precipitation, the climate is warm between October and February, and thunderstorms from March to May [25]. The geographical location is displayed in Fig. 1. 


\subsection{Present scenario}

Solar energy is the safest source of electricity production out of all other resources as Bangladesh gains average solar irradiation of 4 to $6.5 \mathrm{kWhm}^{-2}$ per day [26,27]. In recent times, wind energy is growing as one of the fastest developing renewable energy sectors in Bangladesh [28]. The normal wind turbine speeds in the seashore belt maintain 3 to $4.5 \mathrm{~ms}^{-1}$ in between March and September, while the remainder of the season falling between 1.7 $\mathrm{ms}^{-1}$ and $2 \mathrm{~ms}^{-1}$ [2]. In a hybrid generation model, primarily based on the PV, wind, diesel generator (DG), and battery system, many perspectives have been explored. This model is simulated by HOMER software [8]. Again several HRES configurations have been widely reported, including PV-wind, PV-DG, wind-DG, and micro hydro-DG [3]. Alternatively, as per the authors' statement, biomass is the form of energy that makes up the majority of renewable energy [29]. So, due to the high availability rate of biomass and its power generation possibility, Bangladesh can use this method to enrich the RE programs [12]. Moreover, solar-biomass or biomass powerplants are implemented in many corners of the world and are stated as important renewable resources for the world [26]. The island of St. Martin is too tiny to hold enough biomass to generate enough electricity. However, there is great optimism due to many dairy and poultry farms and available farming lands in the neighboring areas (e.g., Shahporir dwip, Teknaf, Ukhia). Biomass resources can be gathered and produced, and transported then to the power generation station in St. Martin's island [30].

Researchers have investigated the overall power demand in Bangladesh and found that renewable energy might be the possible alternative to conventional fossil fuels for boosting the power demand and energy sustainability [31]. Researchers have also recommended that actions must be taken to promote alternative sources to secure the country's energy security [1]. People have run many simulations combining RE sources with DGs and concluded that solar-wind-diesel is the most practical approach [8]. DGs were used in all the studies mentioned above $[2,3,8,13,22,30,32]$. As a result, there is a possibility of greenhouse gas (GHG) emissions, which can deadly impact on the current eco-life and existing species.

In this study, an HRES model is examined without DGs, resulting in no GHG emissions and $100 \%$ renewable energy production. This study aims to build a fully renewable powerplant using solar, wind resources with a battery bank system and biomass power generation system for additional support.

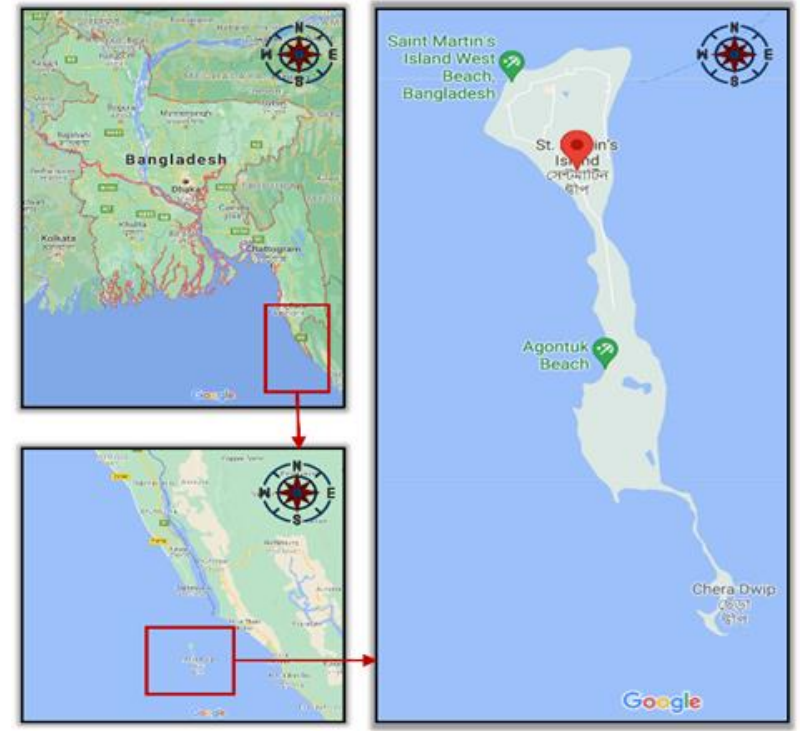

Fig. 1. The location of St. Martin's Island [33].

\section{METHODOLOGY}

\subsection{Load estimation}

About 7000 people are living on St. Martin's island. A community of $\sim 1000$ families, 100 shops, a 10-bed hospital, a 2-storied school, a 2-storied college, 11 mosques, and $\sim 100$ hotels are considered. The approximate load calculations for this study are summarized in Table 1. Data map (DMap) as shown in Fig. 2 illustrates the hourly load demand for a particular day throughout the year. It is seen that the load demand is relatively higher at the beginning and end of a year.

\subsection{PV resources}

Hourly data is not available for PV resources; thus, monthly data is taken from the National Aeronautics and Space Administration (NASA) [34], readily available in HOMER tools that use the Graham algorithm for synthesizing 8760 hourly values for a year. From Table 2 and Fig. 3, it can be seen that the daily radiation and clearness index is low for June, July, and August. The annual average clearness index is found to be 0.527 annually and radiation per day is about $4.8 \mathrm{kWhm}^{-2} /$ day.

\subsection{Wind resources}

The data for wind resources has also been taken from NASA [34]. Four advanced parameters are considered for wind resources. The Weibull value (k) is set around 2 that measures the distribution of the wind speed. The autocorrelation factor that quantifies the randomness of the wind is set to be 0.84 . The diurnal pattern strength has been determined to be 0.26 that implies how vigorously the wind speed differs with time per day. The maximum and average wind speeds are judged to be $6.7 \mathrm{~ms}^{-1}$ and $4.85 \mathrm{~ms}^{-1}$, respectively. It is seen from Table 2 and Fig. 3 that average wind speed is higher in June, July and August that mitigates the shortage of PV power production for having a lower clearness index. 


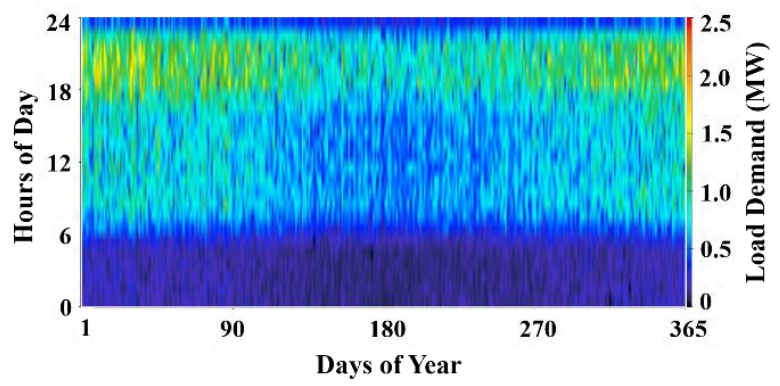

Fig. 2. DMap of load data.

Table 1. The approximate load estimation.

\begin{tabular}{|c|c|c|c|c|c|}
\hline $\begin{array}{l}\text { Load } \\
\text { Profile }\end{array}$ & Component & Number & $\begin{array}{l}\text { Rating } \\
\text { (W) }\end{array}$ & $\begin{array}{c}\text { Hours } \\
\text { Used/Day }\end{array}$ & $\begin{array}{c}\text { Consumption } \\
\text { (kWh/Day) }\end{array}$ \\
\hline \multirow{6}{*}{$\begin{array}{l}\text { Residen- } \\
\text { tial Load }\end{array}$} & Television & $750+250$ & $50+80$ & 12 & $450+240=690$ \\
\hline & Refrigerator & 1000 & 150 & 24 & 3600 \\
\hline & Fan & 3000 & 75 & 20 & 4500 \\
\hline & Light & 5000 & 20 & 8 & 800 \\
\hline & Water Pump & 1000 & 1120 & 0.5 & 560 \\
\hline & Mobile & 3000 & 18 & 4 & 216 \\
\hline \multirow{2}{*}{$\begin{array}{l}\text { A 10-bed } \\
\text { Hospital }\end{array}$} & Fan & 16 & 75 & 20 & 24 \\
\hline & Light & 28 & 20 & 12 & 6.72 \\
\hline \multirow{2}{*}{$\begin{array}{c}\text { A2 2- } \\
\text { storied } \\
\text { School }\end{array}$} & Fan & $14 \times 4=56$ & 75 & 8 & 33.6 \\
\hline & Light & $14 \times 5=70$ & 20 & 8 & 11.2 \\
\hline \multirow{2}{*}{$\begin{array}{c}\text { A 2- } \\
\text { storied } \\
\text { College }\end{array}$} & Fan & $14 \times 4=56$ & 75 & 8 & 33.6 \\
\hline & Light & $14 \times 5=70$ & 20 & 8 & 11.2 \\
\hline \multirow{2}{*}{$\begin{array}{c}11 \\
\text { Mosques }\end{array}$} & Fan & 132 & 75 & 2 & 19.8 \\
\hline & Light & 132 & 20 & 3 & 7.92 \\
\hline \multirow{5}{*}{\begin{tabular}{|c}
$100 \mathrm{Hotels}$ \\
(avg. 20 \\
rooms)
\end{tabular}} & Fan & 2000 & 75 & 12 & 1800 \\
\hline & Tubelight & 2000 & 40 & 10 & 800 \\
\hline & LED Bulb & 6000 & 20 & 10 & 1200 \\
\hline & Television & 600 & 150 & 4 & 360 \\
\hline & Water Pump & 100 & 1120 & 2 & 224 \\
\hline \multirow{3}{*}{100 Shops } & Fan & 100 & 75 & 16 & 120 \\
\hline & Light & 300 & 20 & 16 & 96 \\
\hline & Fridge & 40 & 150 & 24 & 144 \\
\hline
\end{tabular}

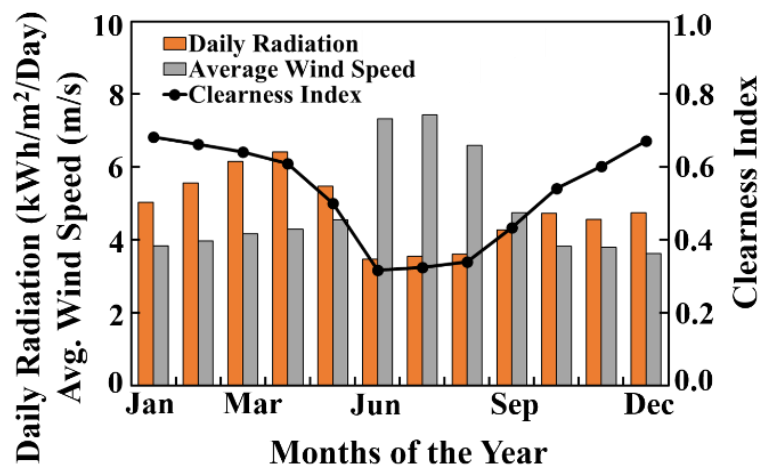

Fig. 3. Monthly PV-wind resource graph.

\subsection{Biomass resources}

Biomass resources in the locations near St. Martin's island are given in Table 3 and Table 4. Due to the insufficiency of its biomass resources, it needs to be transported from Teknaf and Ukhiya. According to the study, resources of 1550 tons/day of cow manure are available along with many other biomass sources (e.g., chicken liters, rice husks) [30]. This mixture carries a high percentage of methane [35]. This study accounted for at least 350 tons/day to be transported for the generation.

Table 2. Monthly PV-wind resource variation.

\begin{tabular}{|c|c|c|c|}
\hline \multirow{2}{*}{ Month } & \multicolumn{2}{|c|}{ PV resource } & $\begin{array}{c}\text { Wind } \\
\text { resource }\end{array}$ \\
\cline { 2 - 4 } & $\begin{array}{c}\text { Clearness } \\
\text { index }\end{array}$ & $\begin{array}{c}\text { Daily } \\
\text { radiation } \\
\text { (kWhm }^{-2} \text { /Day) }\end{array}$ & $\begin{array}{c}\text { Avg. wind } \\
\text { speed } \\
\text { (ms }^{-1} \text { ) }\end{array}$ \\
\hline Jan. & 0.682 & 5.040 & 3.830 \\
\hline Feb. & 0.662 & 5.560 & 3.970 \\
\hline Mar. & 0.642 & 6.160 & 4.170 \\
\hline Apr. & 0.610 & 6.410 & 4.290 \\
\hline May & 0.501 & 5.480 & 4.550 \\
\hline Jun. & 0.316 & 3.470 & 7.330 \\
\hline Jul. & 0.324 & 3.540 & 7.430 \\
\hline Aug. & 0.339 & 3.600 & 6.600 \\
\hline Sept. & 0.433 & 4.270 & 4.740 \\
\hline Oct. & 0.542 & 4.730 & 3.820 \\
\hline Nov. & 0.602 & 4.570 & 3.790 \\
\hline Dec. & 0.672 & 4.740 & 3.630 \\
\hline & & & \\
\hline
\end{tabular}

Table 3. Biomass resource in Teknaf [30].

\begin{tabular}{|l|c|}
\hline \multicolumn{2}{|c|}{ Poultry and Layer Firm } \\
\hline Boiler poultry firm & Quantity \\
\hline Total boiler chicken & 35 \\
\hline Total layer hens (3 firms) & 35000 \\
\hline Total chickens & 38000 \\
\hline \multicolumn{2}{|c|}{ Dairy firm } \\
\hline Total dairy firm & 29 (Recorded) \\
\hline Total cattle & 49000 \\
\hline ** The main crops are rice, betel leaves, and \\
betel nuts. \\
\hline
\end{tabular}

Table 4. Biomass resource in Ukhiya [30].

\begin{tabular}{|l|c|c|c|}
\hline $\begin{array}{c}\text { Poultry } \\
\text { firm's name }\end{array}$ & $\begin{array}{c}\text { No. of } \\
\text { firms }\end{array}$ & Chickens/firm & $\begin{array}{c}\text { Total } \\
\text { Chickens }\end{array}$ \\
\hline Beauty & 53 & 1000 & 53000 \\
\hline Jannat & 60 & 1000 & 60000 \\
\hline Sohel & 9 & 1000 & 9000 \\
\hline Moriccha & 50 & 1000 & 50000 \\
\hline \multicolumn{4}{|c|}{ Dairy Firms } \\
\hline Total dairy firm & 8 (Recorded) \\
\hline Total cattle & 53982 (Recorded) \\
\hline
\end{tabular}

\subsection{Design}

Solar panels for PV, wind turbines for harvesting wind energy, biogas generator for biomass energy, battery bank for storage, and converter devices for converting power from ac to dc and vice versa have been employed. The proposed system has been designed to provide about $15258.04 \mathrm{kWh} / \mathrm{d}$ with a peak load of $2268.31 \mathrm{~kW}$ and simulated using HOMER. HOMER tool integrates all the resources and gives different feasible solutions. Solar panels manufactured by Peimar from Italy will be used 
as the component for producing solar energy. It will be connected to the DC busbar of the proposed model. The chosen solar panel has a lifecycle of about 30 years. For storing the energy produced by the solar panels, there are battery storage components. Battery banks used in this model are manufactured by Generic and its rated capacity is about $1 \mathrm{kWh}$ with a roundtrip efficiency of about $90 \%$. Battery banks are also connected to the DC busbar. For converting the DC power generated by the solar panels into AC power, converters are used that can convert the DC power to the desired AC power. The efficiency of the converter used in this model is about $95 \%$. For wind power generation, a generic $3 \mathrm{~kW}$ wind turbine will be connected to the AC busbar that is manufactured by Generic. For producing biogas from biomass and converting its potential into energy, biogas generators with a rated capacity of $10 \mathrm{~kW}$ have been used and connected to the AC busbar. Its efficiency is about $31 \%$. Fig. 4 demonstrates the design for simulation. Summary of the required components, as presented in Table 5 have been selected based on their properties and costs to reduce the net present cost of the proposed model. The efficiency of the PV is $19.1 \%$, whereas the wind speed for maximum output power is $15 \mathrm{~ms}^{-1}$. The power curve for a wind turbine, as illustrated in Fig. 5, implies that output power initially increases with wind speed (up to $15 \mathrm{~ms}^{-1}$ ) then decreases gradually.

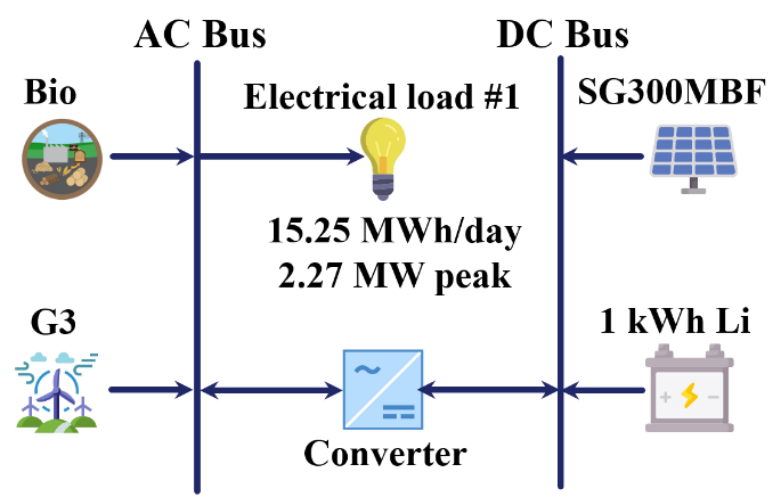

Fig. 4. Schematic design for HOMER simulation.

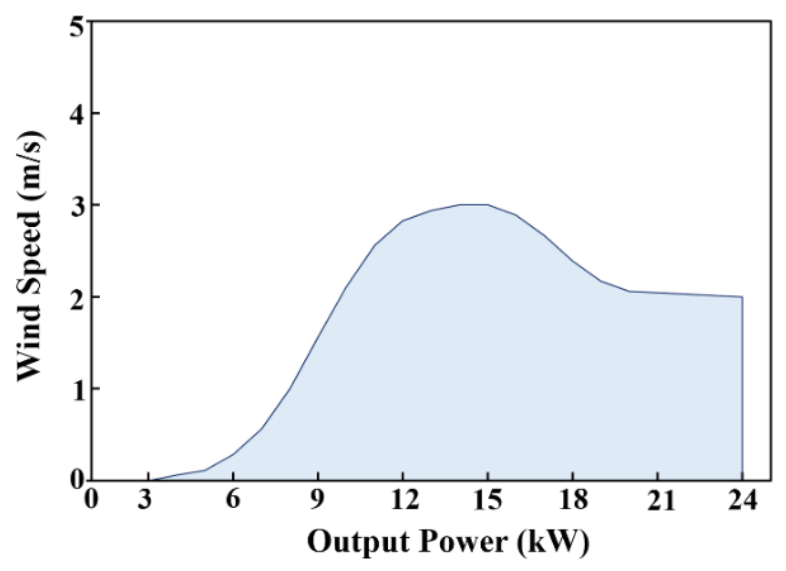

Fig. 5. Power curve of Wind Turbine.
Table 5. Overall summary of the components.

\begin{tabular}{|c|c|c|c|}
\hline Component & Properties & Cost Subjects & $\begin{array}{c}\text { Cost } \\
\text { Amount (\$) }\end{array}$ \\
\hline \multirow{4}{*}{$\begin{array}{c}\text { Peimar } \\
\text { SG300MBF } \\
\text { (For PV) }\end{array}$} & \multirow{4}{*}{$\begin{array}{c}\text { Panel Type: Flat Plate } \\
\text { Rated Capacity }(\mathrm{kW}): 1 \\
\text { Temperature Coefficient: }-0.4 \\
\text { Operating Temperature }\left({ }^{\circ} \mathrm{C}\right): 25 \\
\text { Efficiency }(\%): 19.1 \\
\text { Lifetime: } 30 \text { years } \\
\text { Derating factor: } 80 \%\end{array}$} & Capital Cost & 650 \\
\hline & & Replacement Cost & 650 \\
\hline & & & \\
\hline & & $\begin{array}{l}\text { Operation and } \\
\text { Maintenance }\end{array}$ & $10 /$ year \\
\hline \multirow{3}{*}{$\begin{array}{c}\text { Generic } \\
\text { Wind } \\
\text { Turbine } \\
\text { (For Wind) }\end{array}$} & \multirow{3}{*}{$\begin{array}{c}\text { Rated Capacity: } 3 \mathrm{~kW} \\
\text { Hub Height: } 30 \mathrm{~m} \\
\text { Lifetime: } 20 \text { years }\end{array}$} & Capital Cost & 15,000 \\
\hline & & Replacement Cost & 15,000 \\
\hline & & $\begin{array}{l}\text { Operation and } \\
\text { Maintenance }\end{array}$ & $150 /$ year \\
\hline \multirow{3}{*}{$\begin{array}{c}\text { Generic } \\
\text { Biogas } \\
\text { Generator } \\
\text { (For } \\
\text { Biomass) }\end{array}$} & \multirow{3}{*}{$\begin{array}{c}\text { Rated Capacity: } 10 \mathrm{~kW} \\
\text { Lower Heating Value: } 5.5 \mathrm{MJ} / \mathrm{kg} \\
\text { Density: } 0.720 \mathrm{~kg} / \mathrm{m}^{3} \\
\text { Carbon Content: } 5 \% \\
\text { Sulfur Content: } 0 \% \\
\text { Lifetime: } 20,000 \text { Hours }\end{array}$} & Capital Cost & 3500 \\
\hline & & Replacement Cost & 1500 \\
\hline & & $\begin{array}{l}\text { Operation and } \\
\text { Maintenance }\end{array}$ & $1 /$ hour \\
\hline \multirow{3}{*}{\begin{tabular}{|c|} 
System \\
Converter \\
(for \\
Converter)
\end{tabular}} & \multirow{3}{*}{$\begin{array}{c}\text { Rated Capacity: } 1 \mathrm{~kW} \\
\text { Efficiency: } 95 \% \\
\text { Lifetime: } 20 \text { years }\end{array}$} & Capital Cost & 300 \\
\hline & & Replacement Cost & 300 \\
\hline & & $\begin{array}{l}\text { Operation and } \\
\text { Maintenance }\end{array}$ & 0 \\
\hline \multirow{3}{*}{$\begin{array}{c}\text { Generic Li- } \\
\text { ion Battery } \\
\text { (For Storage) }\end{array}$} & \multirow{3}{*}{$\begin{array}{c}\text { Output Voltage: } 222 \mathrm{~V} \\
\text { Nominal Capacity: } 1 \mathrm{kWh} \\
\text { Roundtrip Efficiency: } 90 \% \\
\text { Initial State of Charge: } 100 \% \\
\text { Minimum State of Charge: } 20 \% \\
\text { Lifetime: } 15 \text { ycars } \\
\text { Throughput: } 3000 \mathrm{kWh}\end{array}$} & Capital Cost & 550 \\
\hline & & Replacement Cost & 550 \\
\hline & & $\begin{array}{l}\text { Operation and } \\
\text { Maintenance }\end{array}$ & $10 /$ year \\
\hline
\end{tabular}

\section{RESULTS AND DISCUSSION}

\subsection{Simulation results}

HOMER simulates the designed model with all the input data supplied and generates various optimization solutions with different setups. Fig. 6 investigates the optimized results obtained from the HOMER tools. The cost summary and monthly average energy production are shown in Fig. 7 and Fig. 8, respectively. It is found that the majority of the cost accounts for PV. The monthly average production of electricity is relatively on the lower side in June, July, and August months as the clearness index for PV is lower. However, the wind speed is relatively high during that time of the year, mitigating the shortage of electricity production. The PV accounts for $\sim 84 \%$ of total energy generation which is from renewable sources with no capacity shortage. The average feedstock required is 19.4 tons/day to produce $\sim 16 \%$ of total energy. The monthly percentage of average electricity production and required inputs for biogas has been shown in Table 6 and Table 7, respectively. 


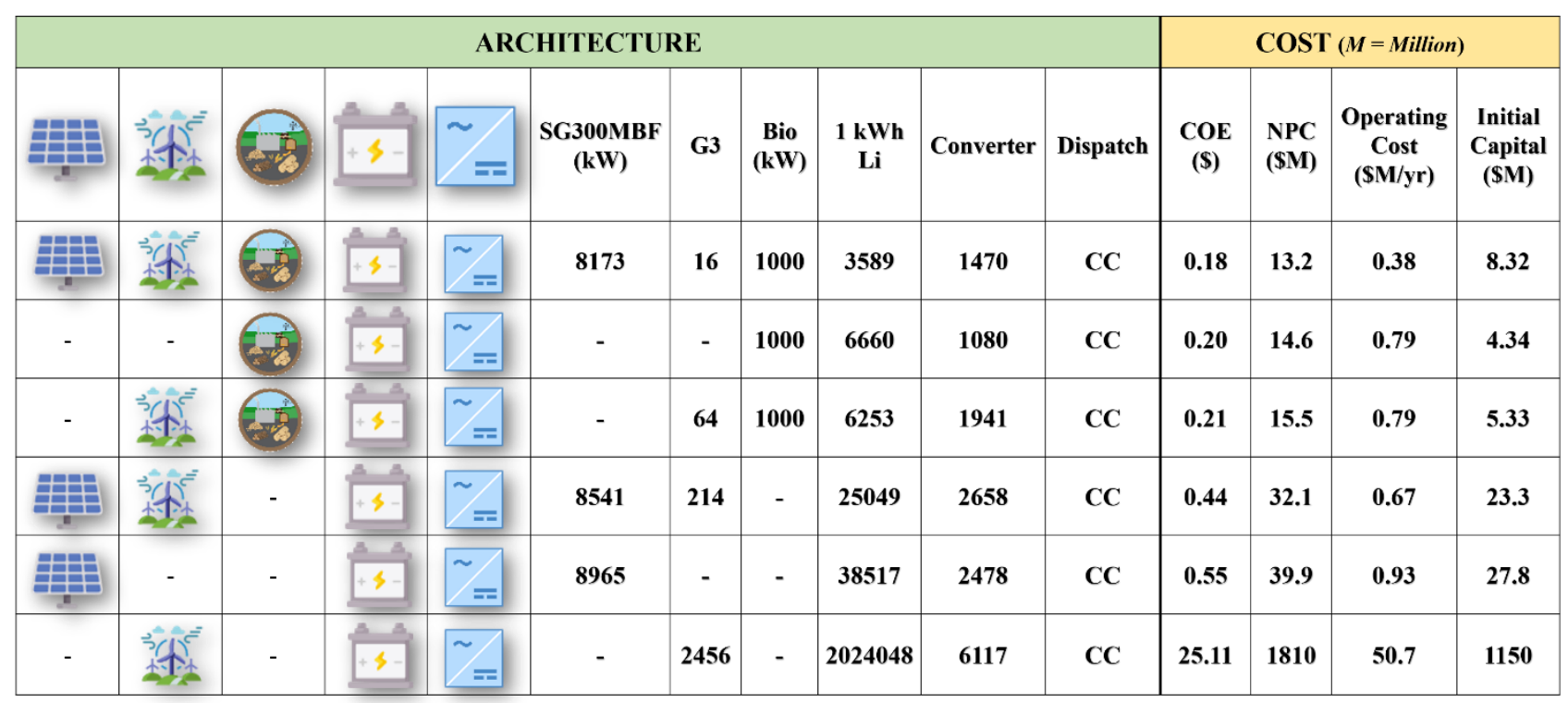

Fig. 6. Optimized results obtained from HOMER tools.

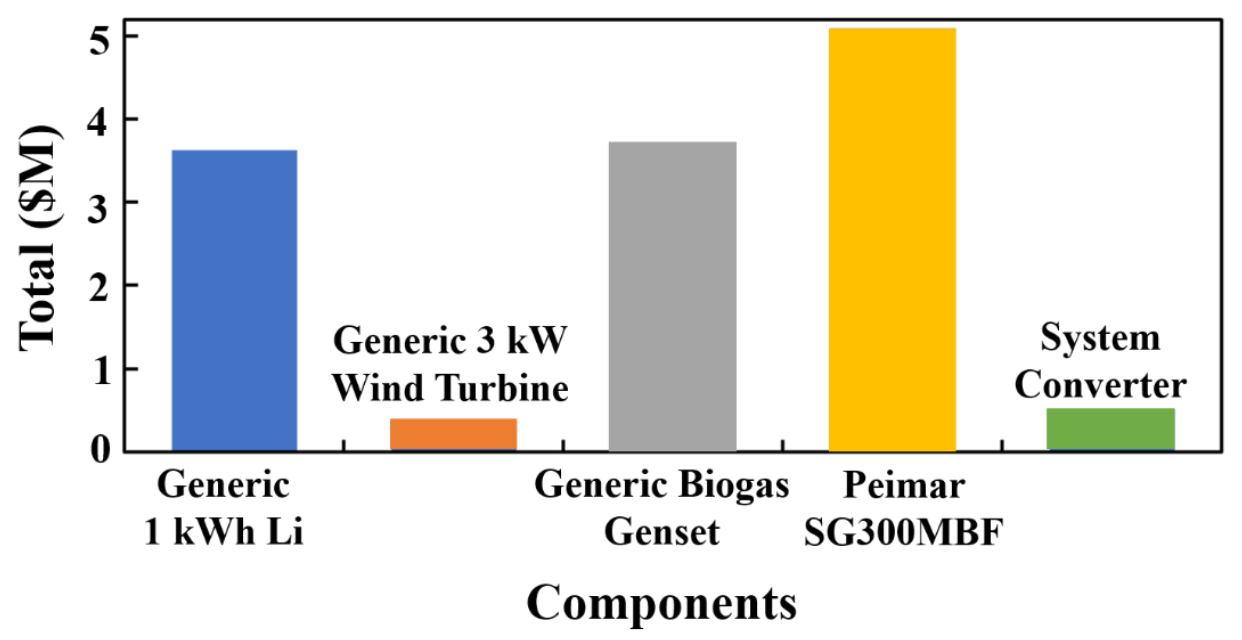

Fig. 7. Cost summary of the simulated model.

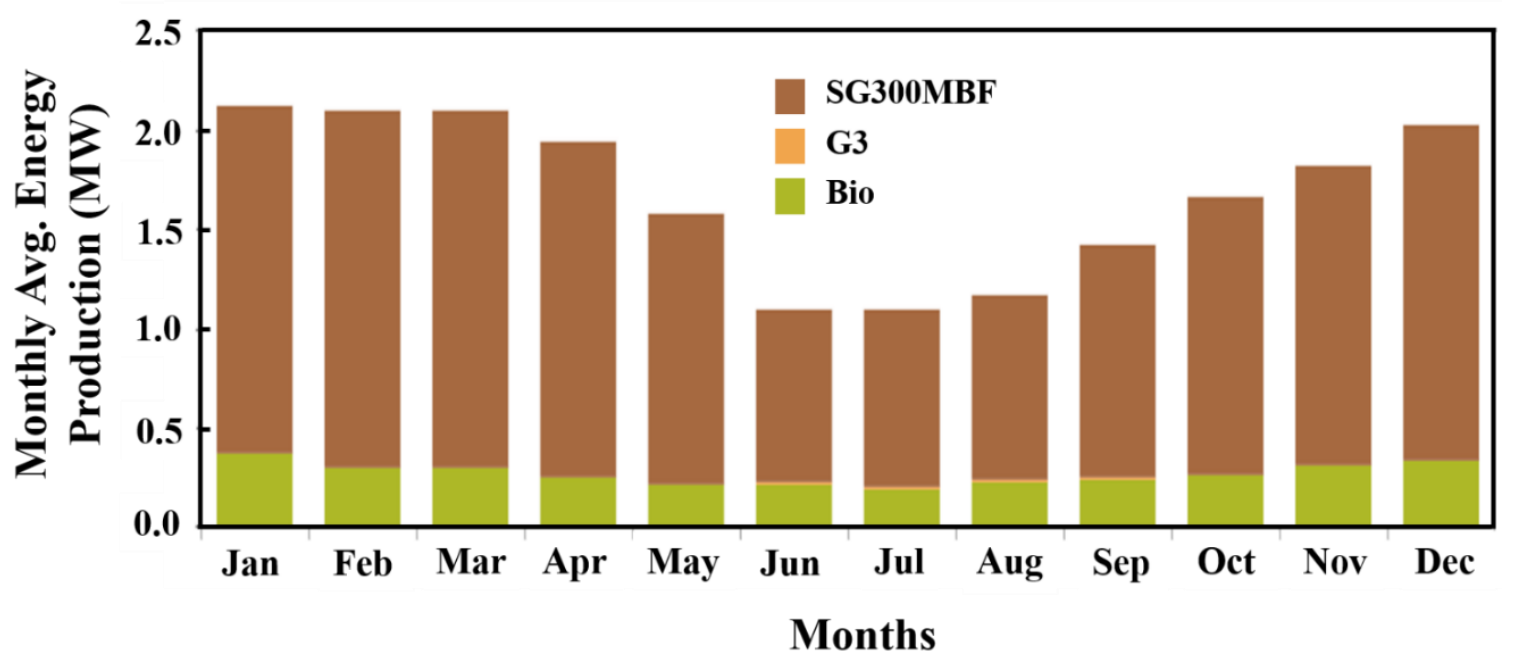

Fig. 8. Monthly average electricity production. 
Table 6 . Average production of electricity.

\begin{tabular}{|l|c|c|}
\hline \multicolumn{1}{|c|}{ Production } & $\mathbf{k W h} / \mathbf{y r}$ & $\boldsymbol{\%}$ \\
\hline Peimar SG300MBF & $12,237,064$ & 83.70 \\
\hline Generic biogas genset & $2,349,416$ & 16.10 \\
\hline Generic 3 $\mathrm{kW}$ wind turbine & 40,957 & 0.280 \\
\hline Total & $14,627,436$ & 100 \\
\hline
\end{tabular}

Table 7. Inputs for biomass energy production.

\begin{tabular}{|l|c|c|}
\hline \multicolumn{1}{|c|}{ Quantity } & Value & Units \\
\hline Total feedstock consumed & 7,066 & tons \\
\hline Avg. feedstock/day & 19.40 & tons/day \\
\hline Avg. feedstock/hour & 0.807 & tons/hour \\
\hline
\end{tabular}

\subsection{Feasibility analysis}

From the simulation, the best possible solution is found having a Net Present Cost (NPC) of about \$13,240,440, Levelized Cost of Energy (COE) as $\$ 0.184$ or $\sim 15$ BDT (1 USD $=84 \mathrm{BDT})$, and an operating cost of $\$ 382,842 /$ year with no capacity shortage. These values are displayed in Table 8. Diesel generators based HRES models revealed the Levelized $\mathrm{COE}$ as $42.17 \mathrm{BDT}$ and emitted a significant amount of $\mathrm{CO}_{2}$ emissions [32]. The emission of different gasses is analyzed and found they tend to be on the lower side in terms of kilograms per year as presented in Table 9.

Table 8. Optimized values for the proposed model.

\begin{tabular}{|l|c|}
\hline \multicolumn{1}{|c|}{ Subjects } & Amount \\
\hline Total NPC & $13,240,440.00$ USD \\
\hline Levelized cost & 0.184 USD or 15 BDT \\
\hline Operating cost & $380,842.00$ USD \\
\hline Capacity shortage & Null or $0 \%$ \\
\hline
\end{tabular}

Table 9. Emission rates of different gasses.

\begin{tabular}{|l|c|}
\hline \multicolumn{1}{|c|}{ Quantity } & Value $(\mathbf{k g} / \mathbf{y r})$ \\
\hline Carbon dioxide $\left(\mathrm{CO}_{2}\right)$ & 1,273 \\
\hline Carbon Monoxide $(\mathrm{CO})$ & 14.1 \\
\hline Unburned hydrocarbons & 0 \\
\hline Particulate matter & 0 \\
\hline Sulfur dioxide $\left(\mathrm{SO}_{2}\right)$ & 0 \\
\hline Nitrogen oxides $\left(\mathrm{NO}_{x}\right)$ & 8.33 \\
\hline
\end{tabular}

\section{CONCLUSIONS}

As the price of fossil fuels has escalated over the past few years, hybrid renewable energy systems (HRES) are more feasible than the conventional technique. In contrast to the grid-connected scheme, HRES, particularly in remote islands, is a promising alternative. Moreover, the price of diesel is rising very quickly in Bangladesh. So, diesel generators would not be viable to use in the future. The studied island (St. Martin) has immense potential for solar PV, wind, and biomass resources. This research work facilitates the most commercially viable alternative to produce energy in that island via HOMER analysis. The results obtained from the feasibility analysis would be helpful to make decisions for preparing and developing the optimum power generation systems in St. Martin's island of Bangladesh.

\section{REFERENCES}

[1] P.K. Halder, N. Paul, M.U.H. Joardder, M. Sarker, Energy scarcity and potential of renewable energy in Bangladesh, Renew. Sustain. Energy Rev. 51 (2015) 1636-1649.

[2] M.M. Karim, M. Anis-Uz-Zaman, A.T. Noman, H. Rashid, M.Z. Al Imran, K.A. Al Mamun, Feasibility Analysis and a Proposal for 1.3 MW Hybrid Renewable Power Plant for Saint-Martins Island Using HOMER, in Proc. of Int. Conf. Electr. Comput. Commun. Eng. (ECCE), 2019 (2019) 1-6.

[3] S. Goel, R. Sharma, Performance evaluation of stand alone, grid connected and hybrid renewable energy systems for rural application: A comparative review, Renew. Sustain. Energy Rev. 78 (2017) 1378-1389.

[4] A.K. Karmaker, M.M. Rahman, M.A. Hossain, M.R. Ahmed, Exploration and corrective measures of greenhouse gas emission from fossil fuel power stations for Bangladesh, J. Clean. Prod. 244 (2020).

[5] P.K. Halder, N. Paul, M.R.A. Beg, Assessment of biomass energy resources and related technologies practice in Bangladesh, Renew. Sustain. Energy Rev. 39 (2014) 444-460.

[6] N. Lior, Energy resources and use: The present (2008) situation and possible sustainable paths to the future, Energy, 35 (2010) 2631-2638.

[7 M.T. Islam, S.A. Shahir, T.M.I. Uddin, A.Z.A. Saifullah, Current energy scenario and future prospect of renewable energy in Bangladesh, Renew. Sustain. Energy Rev. 39 (2014) 1074-1088.

[8] U.S. Mousumi, A. Zardar, K.Z. Islam, TechnoEconomic Evaluation of Hybrid Supply System for Sustainable Powering the Saint Martin Island in Bangladesh, Journal of Energy \& Technology (JET), 1(1) (2021).

[9] T. Shahriar, M.A. Habib, M. Hasanuzzaman, M. Shahrear-Bin-Zaman, Modelling and optimization of Searaser wave energy converter based hydroelectric power generation for Saint Martin's Island in Bangladesh, Ocean Eng. 192 (2019) 106289.

[10] R.K. Pachauri, A. Reisinger, Climate Change 2007 Synthesis Report, website:https://www.ipcc.ch/report/ar4/syr/, (accessed on Jun 17, 2021)

[11] D. Dokken, Intergovernmental Panel on Climate Change 2014, website: https://www.ipcc.ch/report/ar5/syr/, (accessed on Jun 17, 2021).

[12] M.H. Masud, A.A. Ananno, A.M.E. Arefin, R. Ahamed, P. Das, M.U.H. Joardder, Perspective of biomass energy conversion in Bangladesh, Clean Technol. Environ. Policy. 21 (2019) 719-731.

[13] A. Zubair, A. Abdulla Tanvir, M.M. Hasan, Optimal Planning of Standalone Solar-Wind-Diesel Hybrid Energy System for a Coastal Area of Bangladesh, Int. J. Electr. Comput. Eng. 2 (2012) 731-738.

[14] In Mujib Year, Electricity will enlighten every home : PM, (n.d.). http://www.brpowergen.gov.bd/site/news/86a9895ee968-4eb3-9875-6dc3868917d1/ (accessed June 23, 
2021).

[15] Annual Report- 2019-2020 by Power Division, Ministry of Power, Energy and Mineral Resources (MPEMR). website: https://www.mpemr.gov.bd/, (accessed on May 5, 2021).

[16] SREDA. website: http://www.renewableenergy.gov.bd/, (accessed on May 5, 2021).

[17] SREDA and MPEMR. website: https://sreda.portal.gov.bd/site/page/e2e11971-0e8e-

4ef7-b764-f5e09d21f73b/, (accessed on February 11, 2021).

[18] MPEMR. website: https://sreda.portal.gov.bd/site/page/0e65b027-0289-

448c-aec7-2e58c83cfcc2/, (accessed on June 2, 2021).

[19] S.A. Chowdhury, National Solar Energy Roadmap, National Solar Energy Roadmap, (2021) 2021-2041.

[20] M. A. H. Baky, M. M. Rahman and A. S. Islam, Development of renewable energy sector in Bangladesh: Current status and future potential., Renew. Sustain. Energy Rev., 73 (2017) 1184-1197.

[21] MPEMR. website: https://sreda.portal.gov.bd/site/page/676cb08b-17b7-

490c-b94b-d6b71c3ecb19/, (accessed on June 3, 2021).

[22] Abir Hasan, N. Jahan, Roadmap of an Optimized Hybrid Renewable Energy System (HRES) Model in Saint Martin Island, Bangladesh and Simulation of it Using Homer, in Proc. of Int. Conf. Mech. Eng. Renew. Energy, (2013).

[23] M.A. Baki, M.M. Hossain, J. Akter, S.B. Quraishi, M.F. Haque Shojib, A.K.M. Atique Ullah, M.F. Khan, Concentration of heavy metals in seafood (fishes, shrimp, lobster and crabs) and human health assessment in Saint Martin Island, Bangladesh, Ecotoxicol. Environ. Saf. 159 (2018) 153-163.

[24] M. Kamruzzaman, Assessment of Destinationspecific factors of Bangladesh: A review of Saint Martin Island as an emerging Tourist Destination, J. Bus. Stud. XXXIX (2018).

[25] M. Shahadat Hossain, S. Rahman, C. And, M. Rashed-Un-Nabi, Resource Mapping of Saint Martin's Island Using Satellite Image and Ground Observations, J. For. Environ. 5 (2007) 23-36.

[26] T. Srinivas, B. V. Reddy, Hybrid solar-biomass power plant without energy storage, Case Stud. Therm. Eng. 2 (2014) 75-81.

[27] Md. Sakib Hossain and Soad Shajid, Design Optimization, Simulation \& Performance Analysis of 100MW Solar Tower Thermal Power Plant in Cox's Bazar, Bangladesh, in Proc. of Int. Exch. Innov. Conf. Eng. Sci., 6 (2020) 305-312.

[28] J.A. Jacobsson S, The diffusion of renewable energy technology: an analytical framework and key issues for research., Energy Policy 2000 (2000) 625-640.

[29] S.C. Karmaker, M.M. Rahman, B.B. Saha, S. Hosan, The Impact of Biomass Energy Consumption on Human Development: Evidence from Asian Countries, in Proc. of Int. Exch. Innov. Conf. Eng. Sci., 6 (2020) 204-211.

[30] P. Mazumder, M.H. Jamil, C.K. Das, M.A. Matin, Hybrid energy optimization: An ultimate solution to the power crisis of St. Martin Island, Bangladesh, in Proc. of Int. Forum Strateg. Technol. (IFOST), (2014) 363-368.

[31] M.N. Uddin, M.A. Rahman, M. Mofijur, J. Taweekun, K. Techato, M.G. Rasul, Renewable energy in Bangladesh: Status and prospects, Energy Procedia.
160 (2019) 655-661.

[32] H. Jamil, Swarup Chakraborty and Md. Mamunur Rahman, Hybrid Power Optimization in St.Martin Island With Smart Grid Modeling, International Journal of Scientific and Engineering Research, 8(3) (2017) 11591169.

[33] Bangladesh - Google Maps. website: https://www.google.com/maps/place/Bangladesh/@23.6 $34133,88.6128628,7 \mathrm{z} /$ data $=! 4 \mathrm{~m} 5$ !3m4! $1 \mathrm{~s} 0 \times 30$ adaaed 80 e18ba7:0xf2d28e0c4e1fc6b!8m2!3d23.684994!4d90.35 6331 (accessed on June 19, 2021).

[34] NASA Surface meteorology and Solar Energy. website: http://www.eso.org/genfac/pubs/astclim/espas/world/Climate/ITCZ/ION/ionpwv.html (accessed on May 5, 2021).

[35] V.V.N Kishore, Renewable energy Engineering \& Technology: Principles and Practice; Routledge; 1st edition, New Delhi (2009). 